\title{
OPTIMIZATION OF BACTERIOCIN PRODUCTION BY Lactococcus lactis ssp. lactis CN1.10a ORIGIN FROM RUSIPS
}

\section{Optimasi Produksi Bakteriosin yang dihasilkan oleh Lactococcus lactis ssp. lactis CN1.10a Asal Rusip}

\author{
Ninoek Indriati ${ }^{1}$, Arifah Kusmarwati ${ }^{1 *}$ and Irma Hermana ${ }^{1}$ \\ ${ }^{1}$ Research and Development Center for Marine and Fisheries Product Processing and Biotechnology, \\ JI. K.S. Tubun Petamburan VI, Central Jakarta 10260, Indonesia, *Correspondence Author: akusmarwati@gmail.com \\ Article history: \\ Received: 5 August 2014; Revised: 11September 2014; Accepted: 23 November 2014
}

\begin{abstract}
Previous study of bacteriocin production on laboratory scale $(100 \mathrm{ml})$ that used MRS broth medium produced unstable activity of bacteriocin. This study aims to determine the optimum growth conditions and media for production of bacteriocin. Bacteria used in this research was a lactic acid bacteria (LAB) Lactococcus lactis ssp. lactis $\mathrm{CN1} 1.10$ a isolated from rusip, a traditional Bangkanese fermented fish product. The bacteria was first cultivated for subsequent use of bacteriocins production on intermediate scale $(2 \mathrm{~L})$, followed by the optimization of temperature, $\mathrm{pH}$ and medium for the bacteriocin production, determination of cell growth curve, bacteriocin production curve, bacteriocin activity and stability of bacteriocin during storage. Results showed that the optimum temperature and $\mathrm{pH}$ for the growth of producer cell were $28{ }^{\circ} \mathrm{C}$ and $\mathrm{pH}$. The greatest activity of bacteriocin was produced on $\mathrm{CM}$ medium ( $1 \%$ sucrose, $0.45 \%$ peptone, $1 \%$ yeast extract, $2.84 \% \mathrm{KH}_{2} \mathrm{PO}_{4}, 0.2 \% \mathrm{NaCl}$ and $0.02 \% \mathrm{MgSO}_{4} .7 \mathrm{H}_{2} 0$ ) in addition of sucrose as carbohydrate source. Based on the growth curve performed on $\mathrm{CM}$ medium with $\mathrm{KH}_{2} \mathrm{PO}_{4}$, the L. lactis ssp. lactis CN1.10a was relatively stable up to 48 hours. Bacteriocin produced by the cell was $8000 \mathrm{AU} / \mathrm{ml}$ at $24^{\text {th }}$ hour. Bacteriocin was relatively stable when stored at $-20{ }^{\circ} \mathrm{C}$ for 1 month with a relative activity of $69.4 \%$.
\end{abstract}

Keywords: optimization, cell growth curve, production of bacteriocins, Lactococcus lactis, rusip

\section{ABSTRAK}

Studi terdahulu mengenai produksi bakteriosin skala laboratorium (100 ml) yang menggunakan media MRS cair menghasilkan aktivitas bakteriosin yang tidak stabil. Oleh karena itu penelitian ini bertujuan untuk mengetahui kondisi dan media pertumbuhan optimum untuk produksi bakteriosin. Bakteri yang digunakan dalam penelitian ini adalah bakteri asam laktat (BAL) Lactococcus lactis ssp. lactis CN1.10a yang diisolasi dari rusip, produk fermentasi ikan tradisional Bangka. Terlebih dahulu bakteri dikultivasi untuk selanjutnya digunakan untuk produksi bakteriosin skala intermediet (2 L). Kemudian dilanjutkan dengan optimasi suhu, pH dan media untuk produksi bakteriosin, penentuan kurva pertumbuhan sel, kurva produksi bakteriosin, aktivitas bakteriosin serta stabilitas bakteriosin selama penyimpanan. Hasil penelitian menunjukkan bahwa suhu dan $\mathrm{pH}$ optimum untuk pertumbuhan sel produser adalah $28{ }^{\circ} \mathrm{C}$ and $\mathrm{pH}$. Aktivitas bakteriosin terbaik diproduksi pada media $\mathrm{CM}\left(1 \%\right.$ sucrose, $0,45 \%$ peptone, $1 \%$ yeast extract, $2,84 \% \mathrm{KH}_{2} \mathrm{PO}_{4}$, $0,2 \% \mathrm{NaCl}$ and $0,02 \% \mathrm{MgSO}_{4} \cdot 7 \mathrm{H}_{2} 0$ ) dengan sukrosa sebagai sumber karbohidrat. Berdasarkan kurva pertumbuhan pada CM medium dengan $\mathrm{KH}_{2} \mathrm{PO}_{4}$, maka L. lactis ssp. lactis CN1.10a relatif stabil hingga 48 jam. Bakteriosin yang diproduksi oleh sel tersebut adalah sebesar $8000 \mathrm{AU} / \mathrm{ml}$ pada jam ke-24. Bakteriosin relatif stabil ketika disimpan pada suhu $-20^{\circ} \mathrm{C}$ selama 1 bulan dengan aktivitas relatif $69,4 \%$.

Kata Kunci: optimasi, kurva pertumbuhan sel, produksi bakteriosin, Lactococcus lactis, rusip

Permalink/DOI: http://10.15578/squalen.v9i3.107

\section{Introduction}

Bacteriocins are ribosomally synthesized antimicrobial compounds that are produced by many different bacterial species including many members of the lactic acid bacteria (LAB). Bacteriocins are proteinaceous compounds produced by bacteria that exhibit a bactericidal or bacteriostatic mode of action against sensitive bacterial species. These proteins are often active against species closely related to the 
producing microorganism (Klaenhammer, 1988; Kaiser et al., 1993). The primary target of bacteriocins produced by lactic acid bacteria is most probably the cytoplasmic membrane, since they initiate reactions which alter the membrane permeability disturbing membrane transport or dissipating the proton motive force and thus inhibiting energy production and biosynthesis of proteins or nucleic acids. Therefore, the bacteriocin often displays a transmembrane helix or an amphiphilic a-helix (Nissen-Meyer et al.,1992 in De Vyust \& Vandamme, 1994).

Naturally traditional fermented products contain bacteriocins have been consumed for centuries (Smith, 1992 in Bhugaloo-vial et al., 1997). Indonesia has many kinds of fermented fish products, one of them is rusip. Rusip is composed of fish, salt, brown sugar and dried rice but sometimes without rice. It is produced by spontaneous fermentation during 7-14 days anaerobically (Yuliana, 2007). Rusip is mainly produced in Bangka Belitung Provinces and widely used as a condiment or mixed with chilli sauce and consumed with boiled rice and vegetables. Rusip contains mainly lactic acid bacteria (LAB) such as Lactobacillus, Streptococcus, Leuconostoc, Pediococcus, and Enterococcus (Dessi, 1999 in Yuliana, 2007; Wijaya, 2007 in Sakti, 2009). Our previous study showed that the lactic acid bacteria which was isolated from rusip was identified as Lactococcus lactis ssp. lactis CN1.10a. This bacteria could produced bacteriocin. Characteristics of this bacteriocin were sensitive to proteolytic enzymes, i.e. proteinase $\mathrm{K}$ and papain but not to RNAse. The bacteriocin has wide target activity of inhibition against Gram-positive and negative bacteria such as Esherichia coli, Listeria monocytogenes and Lactobacillus plantarum. The activity of bacteriocin could be stimulated by sodium dodecyl sulphate (SDS), lauryl sarcosine and EDTA but strongly inhibited by Tween 20, Tween 80 , Triton X-100 and urea. It was stable at pH 2.0 to 6.0, and also was heat stable $\left(121^{\circ} \mathrm{C}\right)$ (Kusmarwati et al., 2013).

Recently, nisin, produced by strains of Lactococcus lactis, was the only bacteriocin with commercial applications in the food industry. Nisin is a natural antimicrobial peptide produced by Lactococcus lactis subsp. lactis that effectively inhibits Gram-positive and Gram-negative bacteria and also the out growth of spores of Bacilli and Clostridia. Additionally it has been used as a biopreservative and a potential agent in pharmaceutical,veterinary and health care products (de Arauz et al., 2009).

Our previous study on lab scale production (100 $\mathrm{ml}$ ) of bacteriocin from $L$. lactis ssp. lactis $\mathrm{CN1} 10 \mathrm{a}$ resulted bacteriocin with activity of $3.453 \mathrm{AU} / \mathrm{ml}$ and was stable at high temperature $\left(121^{\circ} \mathrm{C}\right)$ (Kusmarwati et al., 2013). In that production, we used MRS broth medium. However, bacteriocin activity produced was unstable. Therefore we need to find a good medium that always produce stable bacteriocin by optimation.

Bacteriocin production is usually proportional to growth and shows primary metabolite, however the correlation is weak (Delgado et al., 2005a in Delgado, A., 2007). Therefore for producing of bacteriocin, it requires a better understanding of the relationship between growth and bacteriocin production, as well as relationship between bacteriocin production and medium.

Studies on optimation and production of bacteriocin produced by Indonesian fermented food are still limited. Some of the results was reported that production of bacteriocin from meat and milk associated lactic acid bacteria (Usmiati \& Marwati, 2007; Syahniar, 2009). Optimal bacteriocin production in batch fermentation usually using complex media and well-controlled physical conditions, such as temperature and $\mathrm{pH}$. Most currently complex media are the concentration of the carbon source, nitrogen source and Tween 80 (Biswas et al., 1991 in Callewaert \& De Vyust, 2000; Keren et al., 2004 in Delgado et al., 2007; Mandal et al., 2008; Anthony et al., 2009; Biscola et al., 2013). Maximum production of bacteriocin ST664BZ was 12,80AU/ml after $23 \mathrm{~h}$ and production remainedstable to the end of growth (Todorov \& Dicks, 2006).

The objectives of this work were to evaluate the effects of the medium components on cell growth, optimum condition and optimum medium composition for bacteriocin production.

\section{Material and Methods}

\subsection{Bacterial Strains and Media}

The bacteriocin producing strain Lactococcus lactis subsp. lactis CN1.10a was isolated from rusip sampel, fermented fish products of Bangkanese origin. Staphylococcus aureus, Listeria monocytogenes and Lactobacillus plantarum was used as indicator organism in the bioactivity of bacteriocin. Bacterial stocks were kept chilled $\left(-4{ }^{\circ} \mathrm{C}\right)$ in MRS medium. This bacteria were inoculated in $10 \mathrm{ml} \mathrm{CM}$ lactose/ CM medium( $1 \%$ lactose, $0.45 \%$ soybean peptone, $1 \%$ yeast extract, $2.84 \% \mathrm{KH}_{2} \mathrm{PO}_{4}, 0.2 \% \mathrm{NaCl}$ and $0.02 \% \mathrm{MgSO}_{4} .7 \mathrm{H}_{2} \mathrm{O}$ ) medium (Li et al., 2002) and incubated during 48 hours at $35^{\circ} \mathrm{C}$, propagated three times before experiment.

MRS broth was used as a medium for optimization of $\mathrm{pH}$ and temperature for bacteriocin production. $\mathrm{CM}$ medium contained different carbohydrate source 
(glucose, sucrose and lactose) was optimized to obtain optimum medium for bacteriocin production. CM medium was also used as a culture medium for Lactococcus lactis ssp. lactis CN1.10a, a bacteriocinproducing strain. There was two initial $\mathrm{pH}$ media. The one was adjusted to $\mathrm{pH} 6$ by adding $1 \mathrm{~N} \mathrm{NaOH}$ and the other was not. Listeria monocytogenes was used as the indicator organism in bacteriocin assay and it was grown on medium TSB (Tryptic soy broth), CM medium and TSB medium were autoclaved at $121^{\circ} \mathrm{C}$ for 15 menit, respectively.

\subsection{Cultivation}

The cells of $L$. lactis ssp. lactis CN1.10a were pregrown in $50 \mathrm{ml} \mathrm{CM}$ medium overnight at $35^{\circ} \mathrm{C}$, and then $10 \mathrm{ml}$ of the culture was added aseptically to $500 \mathrm{ml} \mathrm{CM}$ medium for the optimization in $1 \mathrm{~L}$ bottle with a rubber plug. The culture was shaken at 170 rpm and $(28 \pm 2){ }^{\circ} \mathrm{C}$ aerobically. Samples were taken from the bottle with sterile pipet every three hours during incubation time (48 hour).

\subsection{Bacteriocin Activity}

The agar well diffusion method (Tagg \& Mcgiven, 1971; Ogunbanwo et al., 2003) was used to detect the antibacterial spectrum of crude bacteriocin from L. lactis ssp. lactis CN1.10a. Each of $100 \mu$ indicator strain (Staphylococcus aureus, Listeria monocytogenes and Lactobacillus plantarum) was inoculated into $15 \mathrm{ml}$ Mueller Hinton Agar (0,5 McFrland), and wells (6 $\mathrm{mm}$ diameter) were punched in the plate. Each wells was filled with $30 \mu$ of crude bacteriocin $L$. lactis CN1.10a, L. lactis UGM and Pediococcus acidilactici F-11. The plates were incubated at $35^{\circ} \mathrm{C}$ for $24 \mathrm{~h}$. The diameter of inhibition zones $(\mathrm{mm})$ around the wells was measured. This procedure was repeated three times. The antimicrobial activity recorded as positive if a transparent halo zone was observed around the well. The indicator strains were grown in MRS broth for L. plantarum and $\mathrm{BHI}$ broth for L. monocytogenes and S. aureus and incubated at $37^{\circ} \mathrm{C}$ for $24 \mathrm{~h}$. Antimicrobial activity was expressed as arbitrary unit (AU) per ml. Using this method, one $A U$ was defined as the area of inhibition zone per volume of bacteriocin sample $\left(\mathrm{mm}^{2} / \mathrm{ml}\right)$ (Usmiati \& Marwati, 2007).

$$
\begin{aligned}
& \text { Bacteriocin activity }\left(\mathrm{mm}^{2} / \mathrm{ml}\right)=\mathrm{AU} / \mathrm{ml} \\
& =\frac{\mathrm{Lz}-\mathrm{Ls}}{\mathrm{V}} \\
& \text { Note: } \\
& \mathrm{Lz}=\text { The area of transparent zone }\left(\mathrm{mm}^{2}\right) \\
& \mathrm{Ls}=\text { The area of well }\left(\mathrm{mm}^{2}\right) \\
& \mathrm{V}=\text { Volume of sample }(\mathrm{ml})
\end{aligned}
$$

\subsection{Optimum Temperature for Bacteriocin Production}

Ten (10) $\mathrm{ml}$ of active culture of the strain L. lactis ssp. lactis CN1.10a was incubated at $30,35,37^{\circ} \mathrm{C}$ for 24 hours on MRS medium. The culture was sentrifuged at $4{ }^{\circ} \mathrm{C}, 9.632 \mathrm{xg}$ for 20 minutes; and the supernatant obtained was heated at $80{ }^{\circ} \mathrm{C}$ for 15 minutes. Bacteriocin activities of the supernatants of the cultures were calculated as described above.

\subsection{Optimum pH for Bacteriocin Production}

Samples of MRS broth were prepared by adjusting $\mathrm{pH}$ to $4.0,5.0,6.0,7.0,8.0$, and 9.0 with $0.1 \mathrm{~N}$ or $1 \mathrm{~N}$ $\mathrm{HCl}$ and $0.1 \mathrm{~N}$ or $1 \mathrm{~N} \mathrm{NaOH}$ before sterilization. The tubes containing $10 \mathrm{ml}$ of $\mathrm{pH}$ adjusted MRS broth were inoculated with $100 \mu$ l of active culture of the strain $L$. lactis ssp. lactis CN1.10a and incubated at $37^{\circ} \mathrm{C}$ for $24 \mathrm{~h}$. The culture was sentrifuged at $4^{\circ} \mathrm{C}, 9.632 \mathrm{xg}$ for 20 minutes, and the supernatant which was obtained was heated at $80{ }^{\circ} \mathrm{C}$ for 15 minutes. Bacteriocin activities of the supernatants of the cultures were calculated as described above.

\subsection{Optimization of Media for Bacteriocin Production}

Each of $50 \mathrm{ml}$ of active culture of the strain L. lactis ssp. lactis CN1.10a in CM lactose, CM glucose and $\mathrm{CM}$ sucrose was incubated at $35^{\circ} \mathrm{C}$ for 24 hours. After that, the culture was sentrifuged at $4^{\circ} \mathrm{C}, 9.632$ $\mathrm{xg}$ for 20 minutes. The supernatant which was obtained was heated at $80{ }^{\circ} \mathrm{C}$ for 15 minutes. Antibacterial activity of bacteriocin was assayed to some tested bacteria (L. plantarum, L. monocytogenes, and Staphylococcus aureus) using agar well diffusion method (Ogunbanwo et al., 2003; Udhayashree et al., 2012). This procedure was repeated three times.

\subsection{The Growth Curve and Bacteriocin Production During Growth}

To evaluate the growth of the bacteria in CM broth $\mathrm{pH} 5$ and temperature $35^{\circ} \mathrm{C}$, a total plate count method was used (BSN, 2006). Total bacterial analysis of culture was determined at $0,3^{\text {rd }}, 6^{\text {th }}, 9^{\text {th }}, 12^{\text {th }}, 15^{\text {th }}$, $18^{\text {th }}, 21^{\text {th }}, 24^{\text {th }}, 27^{\text {th }}, 30^{\text {th }}, 33^{\text {th }}, 36^{\text {th }}, 39^{\text {th }}, 42^{\text {th }}, 45^{\text {th }}$, and $48^{\text {th }}$ hour after incubation. For determining bacteriocin production curve, the strain was inoculated into $\mathrm{CM}$ broth (with and without $\mathrm{KH}_{2} \mathrm{PO}_{4}$ ) and incubated at $35{ }^{\circ} \mathrm{C}$ for $48 \mathrm{~h}$. The samples were aseptically withdrawn, in duplicates, from the culture vessel at 3 -h intervals throughout the incubation period. The samples was centrifuged at $4{ }^{\circ} \mathrm{C}, 9.632 \mathrm{xg}$ for 20 minutes. The free cell supernatant which was obtained 
after heated at $80{ }^{\circ} \mathrm{C}$ for 15 minutes was crude bacteriocin. The bacteriocin activities of each sample were calculated and the results were presented along with the growth curve (Van Reenen et al., 1998 in Altuntas et al., 2010).

\subsection{Stability of Bacteriocin During Storage}

Crude bacteriocin was stored at $-20,4$, and 37 ${ }^{\circ} \mathrm{C}$. The reason of bacteriocin storage at $37^{\circ} \mathrm{C}$ was to determine whether the activity of bacteriocin remain stable at high temperature. After 30 days, samples were taken from the stored material to determine bacteriocin activity (Ogunbanwo et al., 2003). L. monocytogenes was used as the indicator organism in bacteriocin activity assays.

\section{Results and Discussions}

\subsection{Optimum Temperature of Bacteriocin Production}

Using the MRS medium, based on Figure 1, the optimal growth conditions which supported maximum bacteriocin production was when it was grown at 35 ${ }^{\circ} \mathrm{C}$ for 24 hours. Bacteriocin at this condition had high activity of $8,500 \mathrm{AU} / \mathrm{ml}$.

\subsection{Optimum $\mathrm{pH}$ for Bacteriocin Production}

Temperature and $\mathrm{pH}$ as well as nutrient availability play a crucial role in bacteriocin production (Lejeune et al. in De Vyust \& Leroy, 2007). Optimal bacteriocin production usually requires complex media and wellcontrolled physical conditions, such as temperature and pH (Anthony et al., 2009; Biscola et al., 2013).

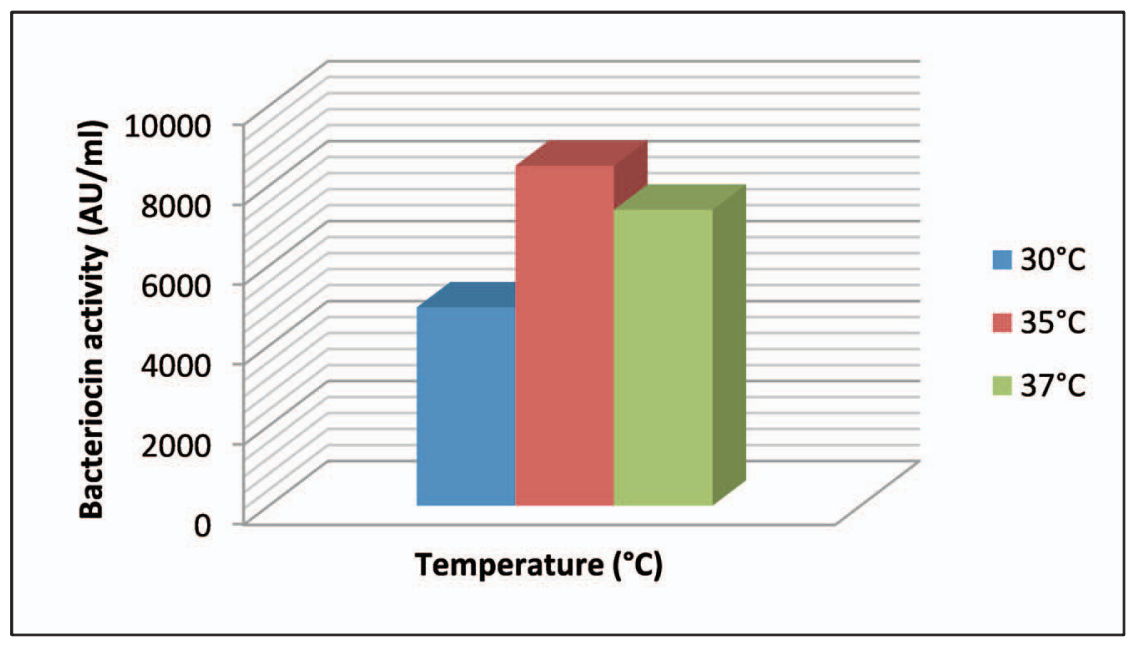

Figure 1. Optimum temperature of bacteriocin productionin MRS medium.

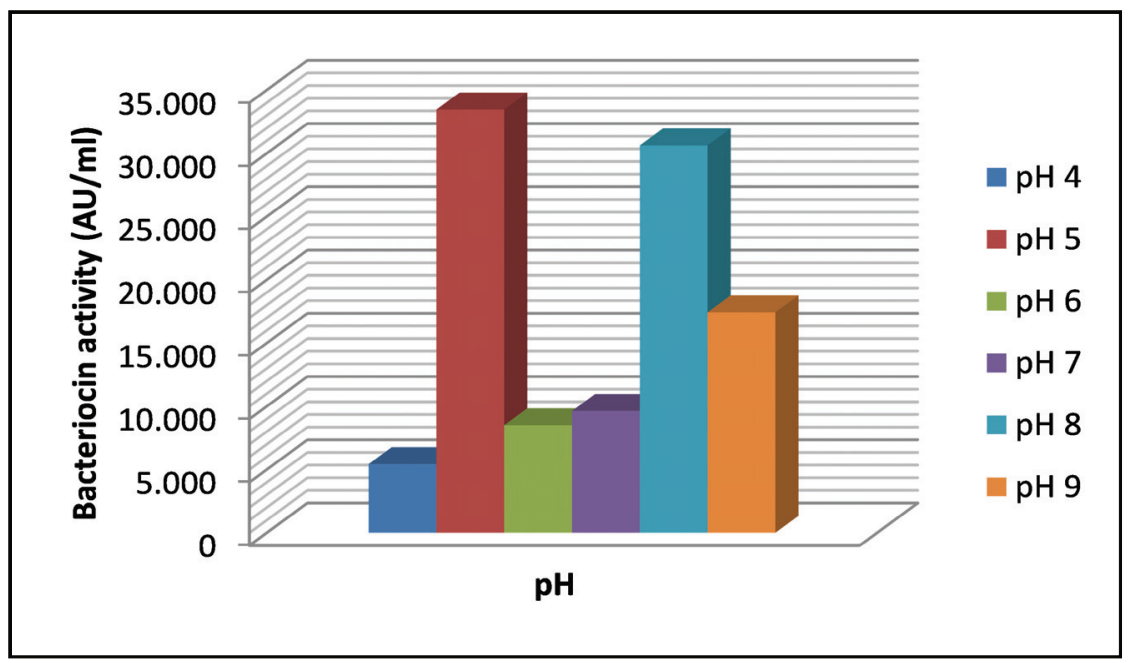

Figure 2. Optimum pH for bacteriocin production in MRS medium. 
Using MRS medium and optimum temperature for bacteriocin as above result, bacteriocin production of L. lactis ssp. lactis CN1.10a was influenced by $\mathrm{pH}$ (Figure 2).

The $\mathrm{pH}$ suitability for better production of bacteriocin at different $\mathrm{pH}$ condition, using MRS medium was in the range of $\mathrm{pH} 4-9$, with optimum $\mathrm{pH}$ at 5 (Figure 2). Bacteriocin at this condition had an activity of $33,456 \mathrm{AU} / \mathrm{ml}$. Meanwhile, the activity of bacteriocin on the other $\mathrm{pH}$ was lower than others. Mandal et al. (2008) reported $\mathrm{pH}$ condition for better production of bacteriocin by Pediococcus acidilactici LAB 5 was in the range of $\mathrm{pH} 5-7$, with optimum $\mathrm{pH}$ at 6.6. In the contrary, Anthony et al. (2009) reported that alkaline $\mathrm{pH}(8.0)$ and high temperature $\left(43^{\circ} \mathrm{C}\right)$ favoured the production of antibacterial peptide by $B$. licheniformis AnBa9.

Based on optimization using MRS medium, it was showed that optimum bacteriocin production was at temperature $35^{\circ} \mathrm{C}$ and $\mathrm{pH}$ 5. Therefore for further study, we used temperature $35^{\circ} \mathrm{C}$ and $\mathrm{pH} 5$ to optimize of production medium of bacteriocin.

\subsection{Optimization of Media for Bacteriocin Production}

Based on this research, MRS broth is one of good medium for improving cell growth of $L$. lactis ssp. lactis CN1.10a, but the bacteria grown at this medium did not always produce bacteriocin or stable bacteriocin. Pediococcus acidilactici LAB 5 failed to produce bacteriocin significantly in MRS medium (Mandal et al., 2008). Therefore, on this work, we used CM medium; and the effects of carbon source (lactose, glucose, and sucrose) in CM medium were evaluated to obtain optimal medium composition for attaining a higher bacteriocin activity (Table 1, 2, 3). CM medium was optimum medium for bacteriocin production by L. lactis ATCC 11454 (Li et al., 2002).

Lactococcus lactis ssp. lactis CN1.10a could produce bacteriocin on $\mathrm{CM}$ medium with lactose and sucrose as carbohydrate source, but the one that grown on $\mathrm{CM}$ medium with glucose could not produce bacteriocin activity. Meanwhile, the activity of bacteriocin on $\mathrm{CM}$ sucrose at $\mathrm{pH} 6$ was higher than CM lactose (Table 2, 3). The reason for $L$. lactis ssp. lactis CN1.10a could produce the highest bacteriocin activity on sucrose-CM medium was most probably corresponded with sugar consumption. Sucrose was consumed faster than lactose or glucose when present as the sole carbohydrate source (Neysens et al., (2003).

\subsection{Cell Growth of Bacteriocin Producer and Bacteriocin Production}

Bacteriocin production on intermediate scale $2 \mathrm{~L}$ was conducted by using shaker at room temperature $(28 \pm 2){ }^{\circ} \mathrm{C}$ for 24 hour. Figure 1 showed cell growth curve of $L$. lactis ssp. CN1.10a lactis on CM medium, medium added with $\mathrm{KH}_{2} \mathrm{PO}_{4}$ and medium without $\mathrm{KH}_{2} \mathrm{PO}_{4}$. The cell growth of bacteriocin producer on $\mathrm{CM}$ medium resulted a higher total bacteria. The concentration of $\mathrm{KH}_{2} \mathrm{PO}_{4}$ strongly affected the cell growth. The function of $\mathrm{KH}_{2} \mathrm{PO}_{4}$ maybe as buffer to stabilize $\mathrm{pH}$ in medium. De Vuyst and Vandamme (1993) in Li et al., (2002) reported that potassium dihydrogen phosphate was able to improve cell growth

Table 1. Activity of bacteriocin (inhibition zone) produced by L. lactis ssp. lactis CN1.10a cultivated on glucose CM medium

\begin{tabular}{llccc}
\hline \multicolumn{1}{c}{ Isolate } & pH condition & \multicolumn{2}{c}{ Inhibition zone (mm) } \\
\cline { 3 - 5 } & & SA & LM & LP \\
\hline L. lactis ssp. lactis CN1.10a & Adjusted pH 6 & 0 & 0 & 0 \\
L. lactis ssp. lactis CN1.10a & Not adjusted & 0 & 0 & 0 \\
L. lactis (UGM) & Adjusted pH 6 & 7.83 & 8.67 & 7.50 \\
L. lactis (UGM) & Not adjusted & 15.67 & 14.33 & 11.00 \\
P. acidilactici & Adjusted pH 6 & 0 & 0 & 0 \\
$P$. acidilactici & Not adjusted & 0 & 0 & 0 \\
\hline
\end{tabular}

Note : SA = Staphylococcus aureus

LM = Listeria monocytogenes

LP = Lactobacillus plantarum 
Table 2. Activity of bacteriocin (inhibition zone) produced by L. lactis ssp. lactis CN1.10a cultivated on lactose-CM medium

\begin{tabular}{llccc}
\hline \multirow{2}{*}{ Isolate } & \multirow{2}{*}{ pH condition } & \multicolumn{3}{c}{ Inhibition zone (mm) } \\
\cline { 3 - 5 } & & SA & LM & LP \\
\hline L. lactis ssp. lactis CN1.10a & Adjusted pH 6 & 8.17 & 7.33 & 7.50 \\
L. lactis ssp. lactis CN1.10a & Not adjusted & 6.83 & 6.83 & 6.83 \\
L. lactis (UGM) & Adjusted pH 6 & 8.33 & 6.83 & 8.17 \\
L. lactis (UGM) & Not adjusted & 7.00 & 7.17 & 6.83 \\
P. acidilactici & Adjusted pH 6 & 0 & 0 & 0 \\
P. acidilactici & Not adjusted & 0 & 0 & 0 \\
\hline
\end{tabular}

Note: SA = Staphylococcus aureus

$\mathrm{LM}=$ Listeria monocytogenes

$\mathrm{LP}=$ Lactobacillus plantarum

Table 3. Activity of bacteriocin (inhibition zone) produced by L. lactis ssp. lactis CN1.10a cultivated on sucrose-CM medium

\begin{tabular}{llccc}
\hline \multirow{2}{*}{ Isolate } & \multirow{2}{*}{ pH condition } & \multicolumn{3}{c}{ Inhibition zone $(\mathbf{m m})$} \\
\cline { 3 - 5 } & & SA & LM & LP \\
\hline L. lactis ssp. lactis CN1.10a & Adjusted pH 6 & 21.00 & 19.50 & 12.33 \\
L. lactis ssp. lactis CN1.10a & Not adjusted & 19.67 & 19.50 & 12.33 \\
L. lactis (UGM) & Adjusted pH 6 & 13.50 & 12.50 & 9.00 \\
L. lactis (UGM) & Not adjusted & 12.50 & 12.33 & 9.00 \\
P. acidilactici & Adjusted pH 6 & 0 & 0 & 0 \\
P. acidilactici & Not adjusted & 0 & 0 & 0 \\
\hline
\end{tabular}

Note: SA = Staphylococcus aureus

$\mathrm{LM}=$ Listeria monocytogenes

LP = Lactobacillus plantarum

and nisin synthesis. Li et al. (2002) reported the concentration of $\mathrm{KH}_{2} \mathrm{PO}_{4}$ strongly affected nisin production. High level of $\mathrm{KH}_{2} \mathrm{PO}_{4}$ concentration $(15 \mathrm{~g} /$ $\mathrm{L})$ allowed the strain to produce a greater nisin concentration than low level of $\mathrm{KH}_{2} \mathrm{PO}_{4}$ concentration (5 g/L). Potassium dihydrogen phosphate, yeast extract, sucrose, and soybean peptone were found to be significant at the probability level of 99 or $95 \%$.

For cell growth of L. lactis ssp. lactis CN1.10a, sucrose, soybean peptone, yeast extract, and potassium dihydrogen phosphate were positively significant factors, but $\mathrm{NaCl}$ and $\mathrm{MgSO}_{4} \cdot 7 \mathrm{H}_{2} \mathrm{O}$ were not found to be significant (Li et al., 2002). Therefore, the different components in medium had different effects on cell growth. According to the research, the highest bacteriocin production at intermediate scale was attained at $24^{\text {th }}$ hour at room temperature (Figure 1).

Generally, bacteriocin activity was detected early in the exponential-growth phase and was produced continuously during this phase. The highest activity was reached at the end of the exponential phase, and corresponded with the maximal total cell. The activity of bacteriocin decreased rapidly when cells entered the stationary phase. Therefore, bacteriocin production follows primary metabolite. Similar metabolite kinetics were previously reported for the bacteriocin amylovorin 1471, a bacteriocin produced by Lactobacilli and $L$. 


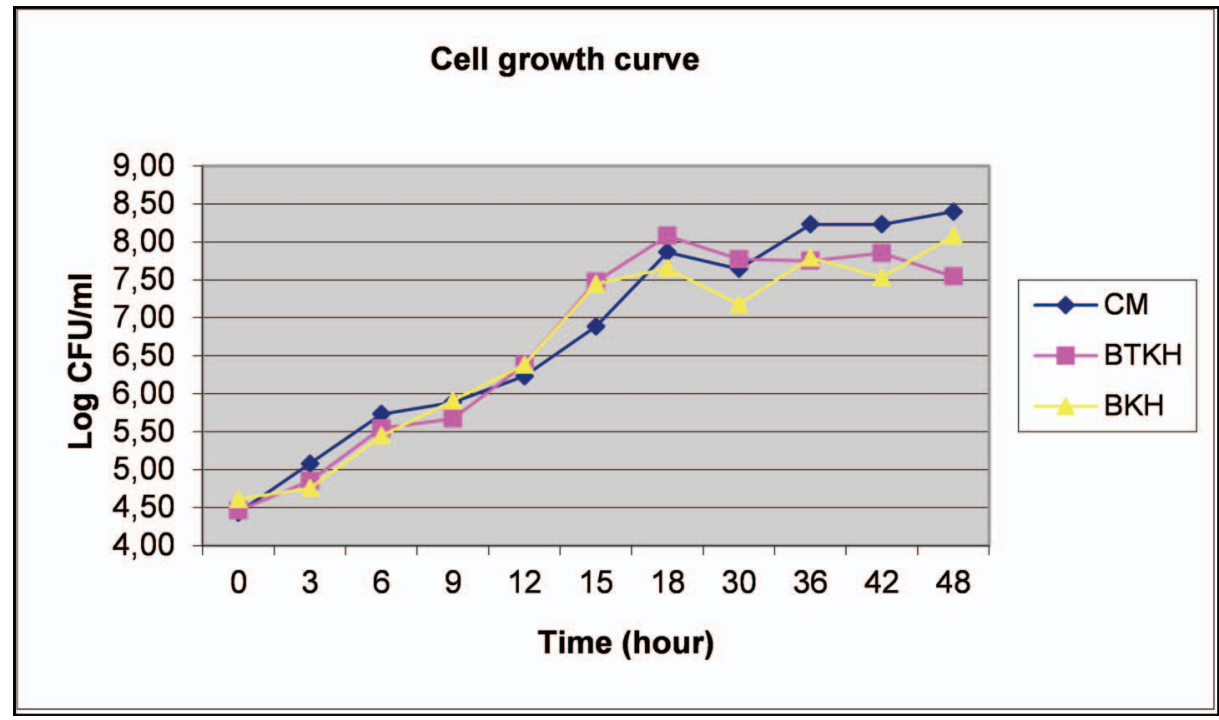

Note: $\mathrm{CM}$ (culture medium); $\mathrm{BKTH}$ (Mix medium without $\mathrm{KH}_{2} \mathrm{PO}_{4}$ ); $\mathrm{BKH}$ (Mix medium with $\mathrm{KH}_{2} \mathrm{PO}_{4}$ ).

Figure 3. Cell growth curve of $L$. lactis ssp. lactis on different media.

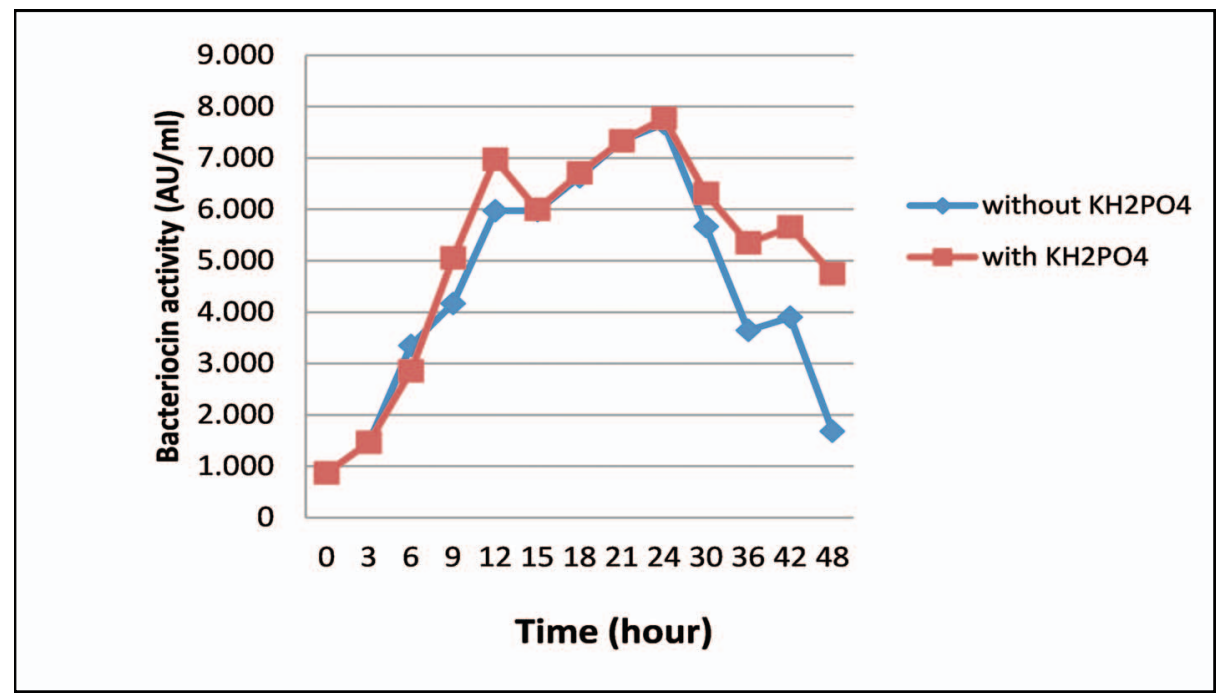

Figure 4. Bacteriocin production curve on different media.

pentosus 31-1 (Neysens et al., 2004; Avonts et al., 2004; Liu et al., 2008). De Vuyst et al. In De Vyust and Leroy (2007) also reported that bacteriocin production is a growth-dependent physiology trait and hence follows primary metabolite. Generally bacteriocin production occurs only in the active growth phase (Parente et al., 1994 in Callewaert \& Vuyst, 2000). Decreasing in activity levels after logarithmic growth has been observed for lactacin $B$, and helveticin $\mathrm{J}$ (Barefoot et al., 1984; Joeger et al., 1986). In many of these cases, loss of activity has been ascribed to proteolytic degradation, protein aggregation, adsorption to cell surfaces and feedback regulation (Parente et al., 1994 in Todorov \& Dicks, 2006).

Based on the result obtained, sucrose-CM medium with $\mathrm{KH}_{2} \mathrm{PO}_{4}$, has been choosen and used it as bacteriocin production medium. Decreasing of total cell slowly on sucrose-CM medium with a present of $\mathrm{KH}_{2} \mathrm{PO}_{4}$ showed that the function of $\mathrm{KH}_{2} \mathrm{PO}_{4}$ was a buffer to mantain stability of $\mathrm{pH}$ in medium. Todorov and Dicks (2004) claimed bacteriocin production was dependent on $\mathrm{pH}$, nutrients source and temperature. Nisin production is affected by several cultural factors such as producer strain, nutrient composition of media, 


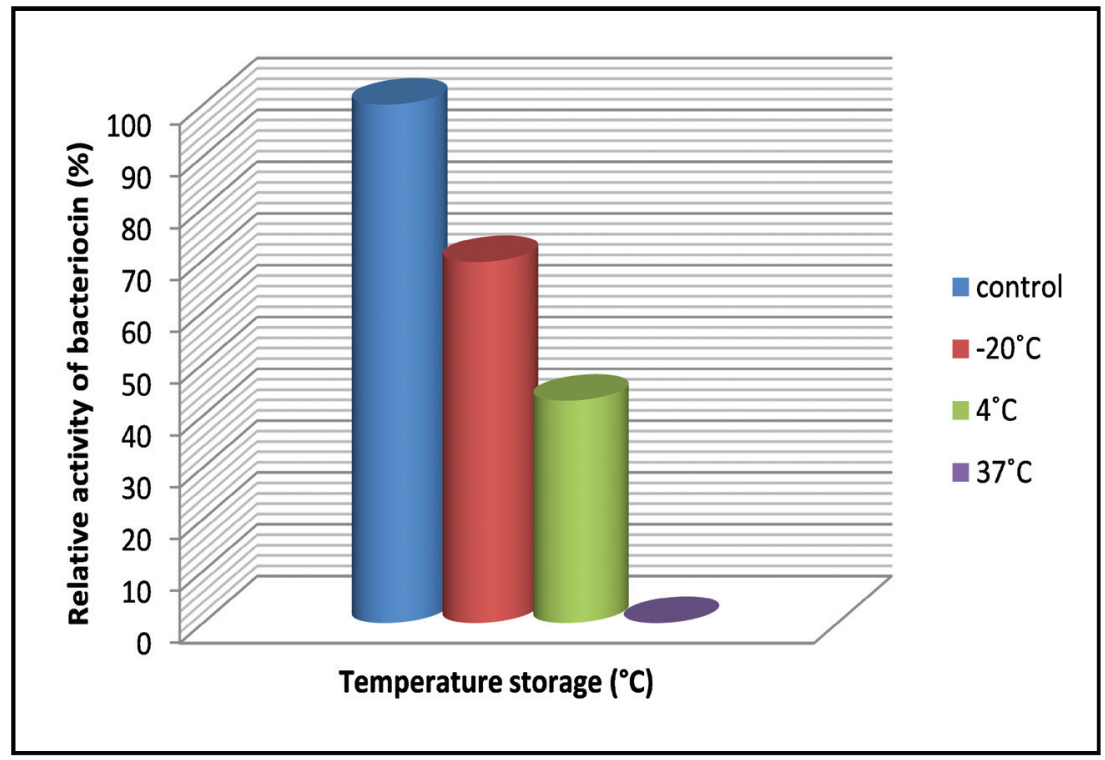

Figure 5. Effect of temperature storage on relative activity of bacteriocin.

$\mathrm{pH}$, temperature, agitation and aeration (Chandrapati \& O'Sullivan, 1998 in Jozala et al., 2011). In addition, the concentration of $\mathrm{KH}_{2} \mathrm{PO}_{4}$ strongly affected bacteriocin production. The same with this research, $\mathrm{Li}$ et al.(2002) reported that the concentration of $\mathrm{KH}_{2} \mathrm{PO}_{4}$ strongly affected nisin production. The high level of $\mathrm{KH}_{2} \mathrm{PO}_{4}$ concentration ( $15 \mathrm{~g} / \mathrm{L}$ ) allowed the strain to produce a greater nisin concentration than the low level of $\mathrm{KH}_{2} \mathrm{PO}_{4}$ concentration $(5 \mathrm{~g} / \mathrm{L})$. Also, nisin production was affected by the level of soybean peptone, decreasing with the elevated concentration of soybean peptone. The other components in the media did not significantly influence nisin production. For bacteriocin production, carbohydrate source from sucrose was able to result in high biomassa and bacteriocin production. Whereas it was different with De Vuyst and Vandamme (1992) in that a high concentration of sucrose was able to result in high biomass, but did not increase the bacteriocin production. Therefore, it was possible to obtain an optimal medium by optimizing the components of medium.

Both $\mathrm{CM}$ medium with $\mathrm{KH}_{2} \mathrm{PO}_{4}$ or without $\mathrm{KH}_{2} \mathrm{PO}_{4}$ produced the highest bacteriocin activity of $L$. Lactis ssp. lactis CN1.10a at $24^{\text {th }}$ hour. However, the activity of bacteriocin on $\mathrm{CM}$ medium without $\mathrm{KH}_{2} \mathrm{PO}_{4}$ decreased faster than with $\mathrm{KH}_{2} \mathrm{PO}_{4}$.

\subsection{Stability of Bacteriocin During Storage}

The stability test of bacteriocin was conducted by storing the bacteriocin at $-20^{\circ} \mathrm{C}, 4^{\circ} \mathrm{C}$, and $37^{\circ} \mathrm{C}$ for 30 days (Figure 5 ).

Bacteriocin produced by $L$. lactis ssp. lactis CN1.10a remained stable (69.4\% activity) after storage for 30 days at $-20^{\circ} \mathrm{C}$, but not detectable after storage for 30 days at $37^{\circ} \mathrm{C}$, indicating the cold temperature may be the most appropriate preservation technique.In addition to the high anti-Listeria activity showed by this bacteriocin and its stability on low temperature, it showed that it was potential use as a food preservative, especially for lightly preserved seafood where Listeria could be a serious problem for its capacity to tolerate refrigerated conditions. Similar activity displayed by pentocin 31-1 produced by $L$. pentosus 31-1 isolated from the traditional China fermented Xuan-Wei Ham were previously reported (Liu et al., 2008). Therefore, more research are needed to study application of this bacteriocin in seafood stored at refrigerated conditions.

\section{Conclusion}

Bacteriocin was produced optimally at temperature $35^{\circ} \mathrm{C}$ and $\mathrm{pH} 5$. Production of bacteriocin on $\mathrm{CM}$ medium was better than those produced in MRS, with lactose and sucrose as carbohydrate source. The optimum condition for bacteriocin production using sucrose- $\mathrm{CM}$ medium was $(28 \pm 2)^{\circ} \mathrm{C}, \mathrm{pH} 6$ with added $\mathrm{KH}_{2} \mathrm{PO}_{4}$. The best storage temperature for bacteriocin was at $-20^{\circ} \mathrm{C}$ with a relative activity of $69.4 \%$.

\section{Acknowledgments}

We thank to Yusma Yennie, the head of Microbiology Laboratory, Research and Development Center for Marine and Fisheries Product Processing and Biotechnology for her technical assistance and provision of laboratory facilities. 


\section{References}

Altuntas, E. G., Cosansu, S., \& Ayhan, K. (2010). Some growth parameters and antimicrobial activity of a bacteriocin-producing strain Pediococcus acidilactici 13. International Journal of Food Microbiology, 141, 28-31.

Anthony, T., Rajesh, T., Kayalvizhi, N., \& Paramasamy Gunasekaran, P. (2009). Influence of medium components and fermentation conditions on the productionof bacteriocin(s) by Bacillus licheniformis AnBa9. Bioresource Technology, 100, 872-877.

Avonts, L., Van Uytven, E., \& De Vuyst, L. (2004). Cell growth and bacteriocin production of probiotic Lactobacillus strains in different media. International Dairy Journal, 14, 947-955.

Barefoot, S. F., Klaenhammer, T.R. (1984). Purification and characterization of the Lactobacillus acidophilus bacteriocin lactacin B. Antimicrob Agents Chemother, 126,328-34.

Biscola, V., Todorov, S. D., Capuano, V. S. C., Abriouel, H., Galvez, A., \& Franco, B. D. G. M. (2013). Isolation and characterization of a nisin-like bacteriocin produced by a Lactococcus lactis strain isolated from charqui, a Brazilian fermented, salted and driedmeat product. Meat Science, 93, 607-613.

BSN (Badan Standardisasi Nasional). (2006). Methods of microbiology assessment. part 3. assay of total plate count on fisheries product. $11 \mathrm{p}$.

Bhugaloo-Vial, P., Grajek, W., Dousset, X., \& Boyaval, P. (1997). Continuous bacteriocin productionwith high cell density bioreactors. Enzyme and Microbial Technology, 21, 450-457.

Callewaert, R. \& De Vyust, L.(2000). Bacteriocin production with Lactobacillus amylovorus DCE 471 is improved and stabilized by fed-batch fermentation. Appl. Environ. Microbiol, 66(2), 606-613.

De Arauz, L. J., Jozala, A. F., Mazzolab, P. V., Vessoni, \& Pennaa,T.C. (2009). Nisin biotechnological production and application: a review. Trends in Food Science \& Technology, 20,146-154.

Delgado, A., L'opez, F. N. A., Brito, D., Peres, C., Fevereiro, P.,\& Garrido-Fern'andez, A. (2007). Optimum bacteriocin production by Lactobacillus plantarum $17.2 \mathrm{~b}$ requiresabsence of $\mathrm{NaCl}$ and apparently follows a mixed metabolite kinetics. Journal of Biotechnology, 130, 193-201.

De Vyust, L. \& Leroy, F.(2007). Bacteriocins from lactic acid bacteria : production, purification, and food applications. J. Mol. Microbiol. Biotechnol., 13, 194199.

De Vuyst, L., \& Vandamme, E. J., (1992). Influence of the carbonsource on nisin production in Lactococcus lactis subsp.lactis batch fermentations. J. Gen. Microbiol.,138, 571-578.

De Vuyst, L. \& Vandamme, E. J. (1994). Bacteriocins of lactic acid bacteria. Microbiology, Genetics and
Applications, Springer Science Business Media New York. Blackie Academic \& Professional. 539 p.

Joeger, M. C. \& Klaenhammer, T. R. (1986). Characterization and purification of helveticin $\mathrm{J}$ and evidence for chromosomally determined bacteriocin produced by Lactobacillus helveticus. 481. J . Bacteriol., 167, 439-46.

Jozala, A. F., Silva, D. P., Vicente, A. A., Teixeira, J. A., Junior, A. P., \& Penna, C. V. (2011). Processing of by products to improve nisin production by Lactococcus lactis. African Journal of Biotechnology, 10(66), 14920-14925.

Kaiser, A. L. \& Montville, T. J. (1993). The influence of pH and growth 24 . rate on production of the bacteriocin, bavaricin $\mathrm{MN}$, in batch and continuous fermentations. J. Appl. Bacterial, 75, 536-540.

Klaenhammer, T. R. (1988). Bacteriocins of lactic acid bacteria. Biochimie, 70, 337-349.

Kusmarwati, A., Indriati, N., \& Hermana, I. (2013). Production and characterization of bacteriocin produced by lactic acid bacteria isolated from rusip. Squalen : Bulletin of Marine and Fisheries Postharvest and Biotechnology, 8 (1), 13-22.

Li, C., Bai, J., Cai, Z., \& Ouyang, F. (2002). Optimization of a cultural medium for bacteriocin production by Lactococcus lactis using response surface methodology. Journal of Biotechnology, 93, 27-34.

Liu, G., Lv, Y., Li, P., Zhou, K., \& Zhang, J. (2008). Pentocin 31-1, an anti-Listeria bacteriocin produced by Lactobacillus pentosus 31-1 isolated from Xuan-Wei Ham, a traditional China fermented meat product. Food Control, 19, 353-359.

Mandal, V., Sen, K. S., \& Mandal, N.C. (2008). Optimized culture condition for bacteriocin production by Pediococcus acidilactici LAB 5 and its characterization. Indian Journal of Biochemistry \& Biophysics, 45, 106-110.

Neysens, P., Messens, W., Gevers, D., Swing, J., \& De Vuyst, L. (2003). Biphasic kinetics of growth and bacteriosin production with Lactobacillus amylovorus DCE 471 occur under stress conditions. Microbiology, 149, 1073-1082.

Ogunbanwo, S. T., Sanni, A. I., \& Onilude, A. A. (2003). Characterization of bacteriocin produced by Lactobacillus plantarum $\mathrm{F} 1$ and Lactobacillus brevis OG1. African Journal of Biotechnology, 2(8), 219-227.

Sakti, T. P. J. (2009). Analysis probiotic of lactic acid bacteria from rusip. Schript. Departement of Agriculture Sriwijaya University. 35 pp.

Syahniar, T. M. (2009). Production and characterization of bacteriosin from Lactobacillus plantarum 1A5 and antimicrobial activity to pathogen bacteria. Schript.IPB Bogor. $61 \mathrm{pp}$. 
Tagg, J. R., \& Mcgiven, A.R. (1971). Assay system for bacteriocins. Applied Microbiology, 21, 9-43.

Todorov, S. D. \& Dicks, L. M. T. (2006). Screening for bacteriocin-producing lactic acid bacteriafrom boza, a traditional cereal beverage from Bulgariacomparison of the bacteriocins. Process Biochemistry, 41, 11-19.

Udhayashree, N., Senbagam, D., \& Senthilkumar, B. (2012). Production of bacteriocin and their application in food products. Asian Pacific Journal of Tropical Biomedicine, S406-S410.

Usmiati, S. \& Marwati, T. (2007). Selection and optimation of process of bacteriocin productionfrom Lactobacillus sp. J. Post Harvest, 4(1), 27-37.

Yuliana, N. (2007). Profile of rusip fermentation made from anchovies (Stolephorus sp). Agritech, 27(1), 1217. 